\title{
The Mozambican Experience in Institutionalizing Agrarian Research
}

\author{
Sérgio Feliciano Come ${ }^{1,2,3}$, Hadma Milaneze de Souza ${ }^{1,4}$, José Ambrósio Ferreira Neto ${ }^{1}$ \\ \& Ana Louise de Carvalho Fiúza ${ }^{1}$ \\ ${ }^{1}$ Department of Rural Economy, Federal University of Viçosa, Brazil \\ ${ }^{2}$ Zambeze University, Mozambique \\ ${ }^{3}$ Institute of Scholarships (IBE), Ministry of Education and Human Development, Mozambique \\ ${ }^{4}$ Council for the Improvement of Higher Education Personnel (CAPES), Brazil \\ Correspondence: Sérgio Feliciano Come, Department of Rural Economy, Purdue Avenue, Campus of Federal \\ University of Viçosa, Viçosa, Minas Gerais, Brazil. Tel: 55-319-8012-0516; 258-825-371-417. E-mail: \\ sergiofcome@gmail.com
}

Received: September 28, 2017

Accepted: November 6, 2017

Online Published: December 15, 2017

doi:10.5539/jas.v10n1p102

URL: https://doi.org/10.5539/jas.v10n1p102

\begin{abstract}
This work addresses the historical process of institutionalization of agrarian research in Mozambique as well as the main challenges that it faces. The study was based on secondary data that address agrarian research from its genesis to the present. The results indicate that in the period prior to Mozambique's independence in 1975, the best agrarian research infrastructures were concentrated in the South of the country, the region with the lowest agricultural potential compared to the Centre and the North. With the independence, the Mozambican Agrarian Research Institute (IIAM), the largest national agrarian research institution, expanded the experimental stations to the Centre and North. However, due to the war that hit the country between 1976 and 1992, agrarian research was not very effective in this period. After the end of the civil war, IIAM and some institutions of higher education, especially Eduardo Mondlane University (UEM), developed several technologies to increase agricultural productivity. Currently, the challenges of agrarian research are enormous, specially the need to: increase the quantity and quality of researchers, study the impact of climate change on agriculture, increase funding for research by government and other national partners, study the causes of the discontinuation of the use of improved agricultural technologies as well as the inclusion of farmers as priority subjects in agrarian research. Improving the linkage between research and rural extension is crucial for the generation and diffusion of appropriate agricultural technologies to the reality of Mozambican farmers.
\end{abstract}

Keywords: agrarian technologies, agriculture, Mozambique, rural areas

\section{Introduction}

Mozambique is a country with an economy based essentially on agriculture. With around $3,828,000$ farms producing mainly maize, cassava, beans and peanuts, the agrarian sector employs about $80 \%$ of the economically active people in the country (INE, 2011). Mozambique's agriculture is mostly practiced by smallholder farmers, which concentrates $99 \%$ of the farms and occupy more than $95 \%$ of the cultivated area (SITOE, 2005). Mozambique has 49 million hectares of arable land, of which only 5 million hectares (ha) are under cultivation (Jasse, 2013).

The average area under cultivation increased $12.4 \%$ between 2002 and 2008 (Table 1). However, according to Cunguara, Garrett, Donovan, and Cássimo (2013), between 2008 and 2012, the average cultivated area decreased from 1.5 ha to 1.4 ha, that we can interpret as a clear situation in which the household farmers reached the limit of the capacity to expand the areas of cultivation, given their technological level (they use the short-handled hoe for farming, for example). Table 1 summarizes the main characteristics of Mozambique's agriculture between 2002 and 2008. In general, the table shows two main contrasting scenarios. The first relates to the fact that, in this period, the total area under cultivation increased $33.9 \%$, the number of small and medium farms increased by $19 \%$, the average household size increased by about $12 \%$, and the rural population increased by $22 \%$. It should be noted that the classification of farms in Mozambique is done using the criteria defined by the National Institute of Statistics (INE, 2009). In this way, Mozambican farms are classified as large, medium and small. In 
order to be considered as a smallholding, the farm must satisfy the following criteria: (a) cultivated area not exceeding 10 ha under dry conditions, (b) cultivated area not exceeding 5 ha in irrigation conditions; (c) cattle population not exceeding 10 heads; (d) have not more than 50 goats, pigs or sheep and (e) have not more than 2,000 birds. Medium-sized farms must meet at least one of the following requirements: (a) area under cultivation between 10 and 50 ha under dry conditions, (b) irrigated area between 5 ha and 10 ha; (c) cattle population between 10 and 100 head; (d) have between 50 and 500 goats, pigs or sheep and (e) have between 2,000 and 10,000 birds. Finally, large holdings must exceed one of the requirements of medium-sized holdings.

The second scenario is related to the use of improved technologies and access to rural extension services and to the credit, which in general reduced significantly between 2002 and 2008. In fact, chemical fertilizers are the only input whose use increased by $8 \%$ while the farmers' access to rural extension services reduced by $39 \%$, use of pesticides reduced by $44 \%$, irrigation of cultivated areas reduced by $19 \%$, and finally, farmers' access to credit also reduced by $10 \%$.

Table 1. Main characteristics of Mozambican agriculture between 2002 and 2008

\begin{tabular}{llllllll}
\hline Description & $\mathbf{2 0 0 2}$ & $\mathbf{2 0 0 3}$ & $\mathbf{2 0 0 5}$ & $\mathbf{2 0 0 6}$ & $\mathbf{2 0 0 7}$ & $\mathbf{2 0 0 8}$ & $\mathbf{\%} \Delta$ between 2002-08 \\
\hline Total cultivated area (000 hectares) & 4185 & 4535 & 5552 & 5612 & 5672 & 5602 & 33.9 \\
Number of small and medium-sized farms (000) & 3127 & 3210 & 3333 & 3396 & 3619 & 3725 & 19.1 \\
Average size of cultivated area (ha) & 1.3 & 1.4 & 1.7 & 1.7 & 1.6 & 1.5 & 12.4 \\
Head's gender (\% headed by men) & 75.7 & 74.3 & 74.8 & 76.7 & 76.5 & 75.9 & 0.3 \\
Household size (average) & 5 & 5 & 5.3 & 5.1 & 4.9 & 5.1 & 2 \\
Rural population in millions (adjusted) & 12.4 & 12.7 & 14 & 13.7 & 14 & 15.1 & 21.5 \\
Heads of household that completed fourth grade (\%) & 31.1 & 32.9 & 36.4 & 36.2 & 36.6 & 42.3 & 36 \\
Received rural extension information (\%) & 13.5 & 13.3 & 14.8 & 12 & 10.1 & 8.3 & -38.5 \\
Used chemical fertilizers (\%) & 3.8 & 2.6 & 3.9 & 4.7 & 4.1 & 4.1 & 7.9 \\
Used pesticides (\%) & 6.8 & 5.3 & 5.6 & 5.5 & 4.2 & 3.8 & -44.1 \\
Irrigated the crops (\%) & 10.9 & 6.1 & 6 & 8.4 & 9.9 & 8.8 & -19.3 \\
Received credit (\%) & NA & 2.9 & 3.5 & 2.9 & 4.7 & 2.6 & -10.3 \\
\hline
\end{tabular}

Note. NA: Not available.

Source: Cunguara et al. (2013).

Still, according to Table 1, we observe that, in terms of technology, Mozambique's agriculture did not evolve during the period in question, which deserves to be studied as it contradicts the efforts of the Ministry of Agriculture to improve the adoption of agricultural technologies by farmers (Uaiene, 2011). Expanding agriculture is essential for the well-being of the population and can be a source for promoting economic growth. Thus, agriculture, through increases in productivity, can benefit both rural and urban poor people by providing them with more food and raw materials at lower prices because of greater production efficiency, which can consequently reduce poverty (Thurlow, 2008; Cunguara et al., 2013). In fact, the increase in agrarian production after the General Peace Agreement signed in 1992 is considered one of the main factors responsible for poverty reduction from 69\% in 1996/97 to 54\% in 2002/03 (Arndt et al., 2006; Cunguara et al., 2013). Another advantage of the growth of agricultural production is related to the links that agriculture has with the rest of the economy (Benfica, 2006), since rural households with higher income from agricultural activities tend to allocate a relatively higher proportion of this income in the purchase of non-agricultural goods, which stimulates the growth of other sectors of the economy.

However, after 2008, the average smallholding farms area and agricultural productivity declined (Cunguara et al., 2013; Mosca, 2011) (Note 1). Several causes can be pointed out to explain the low agricultural productivity, such as the irregular distribution of rainfall, the low use of improved technologies, the precarious state of the road infrastructures that interconnect the South and the North of the country, the low productive capacity of the farmers, the poor access to agrarian rural extension services and credit, among others. The reduction of agricultural productivity occurred in a context of which, there was a prediction of increasing demand for food, fiber, and energy, which would increase the pressure on agricultural research institutions to improve the response that agriculture can give to these scenarios (IIAM, 2010). As can be seen in Table 1, Mozambican agriculture in the period between 2002 and 2008 did not evolve at least in terms of technology adoption, access to credit and 
rural extension services. So, the questions of research are: how has agricultural research been institutionalized in Mozambique? What are the main challenges facing agrarian research today and how can it help improve the performance of Mozambican agriculture? Agricultural research has also served as the bedrock of agricultural technological transformation to enhance agricultural growth. Research has helped to increase agricultural production and productivity and food security in several countries (Seck et al., 2013). Thus, this article aims to analyse the general situation of agrarian research in Mozambique, also pointing out the challenges that it faces. The article was written by consulting scientific articles, dissertations, theses, books and other documents produced by institutions linked to Mozambican agriculture and research. The timeframe of the survey's coverage is from 1975 to 2017. The choice of this period is because there is very little information or documents on agricultural research prior to 1975 , when Mozambique was independent. In addition to documents related to Mozambique's agrarian research, international literature was consulted for comparison purposes. The data identified in the documents were analyzed qualitatively from their contents.

In addition to the introduction, the article is structured in three more sections: the section on the history of agricultural research institutions in Mozambique, followed by the presentation of the challenges of agrarian research in the current context and the final considerations.

\section{Agricultural Research Institutions in Mozambique}

\subsection{Genesis of Agrarian Research}

According to Sitoe (2014), agrarian research in Mozambique is confused with the Mozambican Agricultural Research Institute (IIAM) (Note 2), the country's largest agrarian research institution. With the independence in 1975, the Portuguese colonialists left the country with an infrastructure for agricultural research (experimental stations and laboratory) concentrated in the south of the country, where precipitation and population density are low (Bias \& Donovan, 2003). The southern region of the country presents precipitations lower than 1,000 mm per year, lower than in the central and northern regions of the country. This means that the best infrastructures (laboratories and experimental stations) were concentrated, until independence in 1975, in the region with the lowest agricultural potential. Thus, after independence, it was sought to create conditions for the operation of new stations in the Centre and in the North of the country, with emphasis on the Sussundenga station in the Center and Nampula in the North, aimed at covering all 10 agroecological regions, grouped in three macro-zones, North, Centre and South, that started to carry out adaptive research (Walker et al., 2006). The northern and central areas of Mozambique have good agricultural potential and river basins with more permanent outflow regimes than in the South and have generally more fertile soils. The southern region is characterized by poor sandy soils and a regime of irregular and low precipitation, configuring an unfavorable situation for rainfed agriculture.

From independence to the signing of the General Peace Agreements in 1992, the effectiveness of agrarian research was undermined by political instability and civil war in the country between 1976 and 1992. To cope with the time lost, Mozambican agriculture imported technologies of the world, like the improved maize varieties from neighbouring countries, particularly Zimbabwe, adapted varieties of beans from Colombian, cotton varieties with a higher percentage of ginning from West Africa, vaccines from an Australia-funded project to fight Newcastle disease in chickens, control of cashew diseases through a spraying program from Tanzania and a charcoal production technology from Thailand (Walker et al., 2006). Therefore, during this period, there was practically no generation of indigenous technologies.

The literature that deals with the generation and adoption of agricultural technologies in Mozambique are scarce in terms of analyzing the conditions under which these technologies were appropriated by farmers, with little evidence of the relationship between imported technologies and farmer's needs. After 1992, when Mozambique began to live in a period of greater political stability, the research carried out internally became more prominent, which turned more directly to the demands of local farmers. Thus, it was possible for Mozambican research to identify a local variety of cassava tolerant to root rot, whose economic impact on revenue generation was estimated at USD 8,000,000 per year. Corn varieties such as Matuba were also developed in partnership with the International Institute of Tropical Agriculture (IITA) and the International Maize and Wheat Improvement Center (CIMMYT). Rosette-resistant peanut varieties (Nametil) from the International Crops Research Institute for the Semi-Arid Tropics (ICRISAT) and sweet potato with orange pulp varieties from the International Potato Centre (CIP) were also tested and popularized (Walker et al., 2006). Therefore, at this stage, the Mozambican research entered a circuit of participation in international agrarian research networks, which has contributed to leverage research in the country. 


\subsection{Research Priorities in the Field of Crop Production}

According to Walker et al. (2006), post-1992 agricultural research priorities in Mozambique were established for a time horizon of 15 to 20 years and also according to the zone centres of IIAM. In general, the priority crops were maize and cassava, while peanuts were given second priority. These priorities were highlighted by the fact that maize is grown by $80 \%$ of farmers and cassava by $76 \%$ of them (Sitoe, 2014). In the livestock area, the priorities were for research on raising chickens and goats. Chickens are very important in households in Mozambique. Tomo (2009) states that about $70 \%$ of rural families raise chickens in Mozambique and that they constitute a source of income, which can be used to overcome famine periods. We could note that, for example, when drought and Newcastle disease occurred in 2005, the proportion of households raising chickens fell between 2002 and 2005 (Mather et al., 2008; Cunguara et al., 2013).

We thus perceived that the general priorities of agrarian research were focused on crops cultivation and small animals' husbandry, which, according to Walker et al. (2006), would have the potential to reduce the problems of food insecurity and poverty in the country. The increase in maize and cassava productivity by $20 \%$, according to the authors, would have the potential to reduce overall poverty by $7 \%$ and $6 \%$, respectively. After the publication of the research of Walker et al (2006), there was a workshop that defined transversal research priorities in the area of agricultural production (Falcão \& Egas, 2008). Table 2 presents the main research priorities in the area of agricultural production. We can see that there has been a concern to explore biotechnology to generate genetic material that best responds to environmental adversities. The table also shows the research's concern to develop technologies that increase agricultural productivity and post-harvest operations in order to reduce losses. Finally, the holding of inventories and surveys with farmers was also highlighted as a priority for the success of agriculture. Another concern of the research was related to phytosanitary control aimed at the management of pests, diseases, and weeds. Also, soil conservation practices were strengthened with the use of green manuring and rotation with legumes.

Table 2. Main priorities of the research in the field of agricultural production

\begin{tabular}{ll}
\hline Topic & Details \\
\hline Biotechnology use & $\begin{array}{l}\text { Evaluation, testing and introduction of genetic material (germplasm, varieties, hybrids, and clones) } \\
\text { better adapted to existing environmental conditions (including drought), with higher productivity, } \\
\text { adequate to the market, with tolerance or resistance to major pests and diseases, free of contaminants } \\
\text { (use of biotechnology). }\end{array}$ \\
$\begin{array}{l}\text { Integrated management of pests, diseases, and weeds, including birds, insects, nematodes, fungi, } \\
\text { bacteria, viruses, weeds and parasitic plants, as well as cleaning and material multiplication aspects of } \\
\text { vegetative propagation. }\end{array}$ \\
$\begin{array}{l}\text { Integrated management of soil fertility, including conservation agriculture, use of inorganic and } \\
\text { organic fertilization (manure, compound, and mulching) and the use of legumes. }\end{array}$ \\
Soil management & $\begin{array}{l}\text { Increased productivity of cropping systems (pure, intercropping or mixed cropping) through the use } \\
\text { of improved agronomic practices adapted to prevailing socio-economic conditions, including land use } \\
\text { intensification systems (irrigation), use of animal traction and soil preparation and soil frame system. }\end{array}$ \\
production systems & $\begin{array}{l}\text { Improvement of the post-harvest process, including improvement of drying conditions and processing } \\
\text { at the producer's level, of the quality adapted to the market, agro-processing, and development of } \\
\text { Post-harvest techniques }\end{array}$ \\
alternative products and commercialization. \\
Conducting inventories and surveys.
\end{tabular}

Source: Adapted by the authors from Falcão and Egas (2008).

\subsection{Research Priorities in the Field of Livestock}

In relation to livestock production, six priority topics for research were selected, as we present in Table 3 . Biotechnology, once again, appears as an essential tool to be used by research in order to develop vaccines for animals and also for their genetic breeding for better adapting to the adverse environment's conditions. Research aimed at identifying alternatives for animal feeding was also considered a priority. The development of techniques for the construction of corrals with low-cost material was also considered a priority in agrarian research, as well as the research focused on the processing of products of animal origin in standards compatible with hygiene rules, as can be observed in Table 3 . 
Table 3. Main priorities of the research in the field of livestock

\begin{tabular}{|c|c|}
\hline Topics & Details \\
\hline Animal diseases control & $\begin{array}{l}\text { Identification and control of diseases at the producer level, including the development and use of } \\
\text { vaccines. }\end{array}$ \\
\hline Alternatives for animal feeding & $\begin{array}{l}\text { Identification, testing, and dissemination of alternative food technologies adapted to rural } \\
\text { producers (household farmers) to ensure better nutrition and growth of animals, including critical } \\
\text { annual cyclical periods and the period before sales. }\end{array}$ \\
\hline Genetic improvement of animals & $\begin{array}{l}\text { Adaptation and genetic improvement of the main domestic and domesticated species of animals, } \\
\text { including the determination and application of selection criteria adapted to the socioeconomic } \\
\text { conditions prevailing in rural areas. }\end{array}$ \\
\hline Animal housing technologies & $\begin{array}{l}\text { Improvement and dissemination of low-cost housing technologies adapted to smallholder rural } \\
\text { farmers. }\end{array}$ \\
\hline $\begin{array}{l}\text { Processing technologies for animal } \\
\text { products and their derivatives }\end{array}$ & $\begin{array}{l}\text { Testing and introduction of techniques for the processing of animal products and their derivatives, } \\
\text { with special attention to aspects of public health and commercialization. }\end{array}$ \\
\hline Animal husbandry technologies & $\begin{array}{l}\text { Improvement of management practices to reduce pups mortality, and adequate use of animal } \\
\text { traction. }\end{array}$ \\
\hline
\end{tabular}

Source: Adapted by the authors from Falcão and Egas (2008).

The prevalence of low levels of agricultural production justifies the need to use biotechnology to generate bred genetic materials to replace current ones. However, according to Luby, Kloppenburg, Michaels, and Goldman (2015) one of the negative consequences of the use of improved genetic materials is the loss of biodiversity as it has happened in developed countries. The priorities of Mozambican agrarian research, therefore, fail to take into account that the introduction of improved plant and animal materials may mean a loss of biodiversity, which may also reduce the source of material for the removal of genes for the benefit of the own breeding of plants and animals. Luby et al. (2015) argue that many traditional plant varieties are gene sources for plant breeding programs. However, according to these authors, many research centres do not seem to prioritize studying how they will explore the millenarian knowledge that farmers and animal breeders have about traditional plant and animal species.

\subsection{Research Priorities in the Forest Sector}

Regarding the main research priorities in the forest field, according to Falcão and Egas (2008), there are forest plantation, sustainable management of natural forests, community forests and wildlife management, logging, transport and wood processing technologies, forest economics and policy, watershed management and rehabilitation of degraded areas, forest ecology and environment, conservation of forest genetics and tree breeding. Somehow, research in this area is related to the fact that the use of forest resources is unsustainable as there is increased deforestation and high wastes of forest products. For example, according to Cuvilas et al. (2010) and Cunguara et al. (2013), at the end of the 1980s there was natural vegetation about $60 \mathrm{~km}$ from the metropolitan region of Maputo. However, in 2013, Maputo city received firewood and charcoal from the provinces of Inhambane and Sofala, which are about $600 \mathrm{~km}$ distant. It shows that deforestation is proceeding at a rapid pace, especially around the large cities.

he uses of forest resources is associated with the cultivation of other products, such as tobacco, which is very demanding in terms of drying the leaves, carried out with the use of firewood. Thus, given the importance of wood as the basis for the viability of other crops, research in the area of forest resources has become a priority (Cunguara et al., 2013). A general analysis that can be done about the priorities of Mozambican agrarian research is the fact that it did not include the farmer in the research (Cavane et al., 2013). Farmers as active subjects in agrarian production deserve to be investigated because in an expressive way the success or failure of the performance of agriculture depends largely on them. For example, Cunguara et al. (2013) point out that one of the reasons for low agricultural productivity is the low productive capacity of farmers. We understand, in this way, that the inclusion of the farmers as subjects that need to be researched may be relevant for the increase of the contribution of the research in the agriculture of Mozambique.

The following topic continues to summarize the process of institutionalizing agricultural research in Mozambique, focusing now on the institutional framework, partnerships and received support. 


\subsection{Institutional Framework, Partnerships and Support for Agrarian Research in Mozambique}

In Mozambique, all scientific research, including agriculture one, is coordinated by the Ministry of Science and Technology, Higher Education and Professional Technician (MCTESTP). Among the institutions that work in agrarian research there are: the Department of Policy Analysis (DAP) of the Ministry of Agriculture and Food Security, the Centre for the Promotion of Agriculture (CEPAGRI) and the National Directorate of Studies and Policy Analysis (DNEAP) of the extinct Ministry of Planning and Development. However, this investigative framework has not been sufficient to avoid the reduction of the number of researchers and the reduction of publications (Cunguara et al., 2013). Falcão and Egas (2008) show that the main organizations that cooperate in the area of agrarian research are public institutions. Of these, the authors highlight IIAM and Eduardo Mondlane University (UEM). In fact, UEM, the oldest institution of higher education in Mozambique, has two faculties and two higher schools that offer courses in agrarian science, with emphasis on agronomic engineering, forestry engineering and veterinary medicine. The Faculty of Agronomy and Forestry Engineering (FAEF) and the Faculty of Veterinary Medicine (FAVET) have more than 50 years of experience offering undergraduate courses and a little more than 15 years in postgraduate programs, specifically at the academic master's degree. As institutions of higher education, FAEF and FAVET have also carried out various searches in the field of agricultural science, taking into account the long experience of the professors that translates in many scientific publications. In recent years, there has been a boom in higher education institutions (public and private) that have somehow contributed to agricultural education and research. These are the cases of the Catholic University of Mozambique, which offers undergraduate courses in agrarian sciences since 1995, the Mussa Bin Bique University, the Polytechnic Higher Institutes (of Gaza and of Manica) which offer courses in agricultural sciences such as agricultural engineering, zootechnics and forestry engineering since 2005. Between 2007 and 2009, two public universities, Lúrio and Zambeze, started operating. One of the faculties of Lúrio University is dedicated to offering undergraduate courses in rural development and forest engineering. Zambeze University has three faculties offering courses in agrarian sciences, highlighting the agronomic, forestry, agricultural and agricultural and environmental engineering. The University of São Tomás de Moçambique introduced the undergraduate agricultural and rural extension courses between 2009 and 2011, while the Pedagogical University introduced in 2009, in most of its delegations, the graduation course in agriculture and livestock. However, many of these institutions operate with major resource constraints, from materials, infrastructure, human and financial. For example, according to Langa (2012), UEM came to rely on more than $50-60 \%$ of its total budget on external aid. Even so, the contribution of higher education institutions in agrarian research in Mozambique cannot be overlooked. As for the private sector, its contribution to agrarian research in Mozambique is extremely insignificant (Sitoe, 2014).

In addition to the above referenced institutions, there are other partners who work in agrarian research in the country. These are the Government (through the ministries and extension services), farmers' associations, the private sector, NGOs, and research funding agencies. In most cases, the relationship between the different actors is informal as the parties act to respond to very specific issues. In some cases of formal relationship, the instrument used is the memorandum of understanding. According to Falcão and Egas (2008), in Mozambique, there is no body that is in charge of coordinating the entire agrarian research system.

The link between agrarian research and rural extension in Mozambique is weak, which significantly limits the potential of these institutions to improve agrarian production and productivity. In fact, the weak link between research and extension is a problem characteristic of developing countries (Anandajayasekeram, Ranjitha, Sindu, $\&$ Dirk, 2008). There is evidence of inadequate technological messages from rural extension services (Snapp et al., 2003; Cunguara \& Moder, 2011). At the root of this weak link between extension and agrarian research is the scarcity of resources on the part of these two institutions (Gemo, Eicher, \& Teclemariam, 2005). Removing obstacles that prevent a strong link between extension and research can help improve the effectiveness of extension work and agricultural research.

\section{Challenges of Agrarian Research in Mozambique}

Agricultural research in Mozambique faces, as already described, a series of difficulties in effectively responding to its mission of contributing to the generation of knowledge and technologies that help to promote agrarian production and productivity. According to Cunguara et al. (2013), the average of the agricultural area cultivated in Mozambique tends to decrease, being therefore crucial that the research points out strategies to circumvent or mitigate this problem. The adoption of agricultural technologies is still very low in Mozambique, although the Ministry of Agriculture makes a lot of efforts to reverse the scenario (Uaiene, 2011). For example, less than 7 percent of farmers who grow corn, a staple crop, use improved varieties, less than 5 percent of farmers use pesticides and fertilizers. Efforts by state institutions (Ministry of Agriculture and Food Security) as a strategy 
for farmers to adopt modern technologies show that they have a belief in the positive effect of technology adoption. According to Romeiro (2007), the agrarian development could be effected either through the intervention of capitalist power or through the State. For the part that defends that agriculture is a subordinate and passive sector to the process of capitalist modernization, the State would play a fundamental role in the development of the sector by subsidizing agricultural prices and investing in research and rural extension. In recent years, some studies have been carried out aiming to identify the causes of the low adoption of modern technologies in Mozambican agriculture, especially the work of Cavane et al. (2013). These authors systematized the adoption of agricultural technologies in the country. The results pointed to the intervention of factors such as education level of farmers, biophysical aspects (agro-ecological zones), farmers' access to credit and to rural extension in the adoption of agricultural technologies. On the other hand, a tendency of the discontinuity of the use of agricultural technologies was identified, which deserves in-depth studies on the reasons for this discontinuity.

Kit (2000) also identified the main constraints affecting agricultural research in Mozambique, noting in particular the scarcity of skilled managers and researchers, as well as limited financial resources, the infrastructure aspects, the inadequate establishment of priorities and inadequate stakeholder participation. Cavane et al. (2013) also draw attention to the fact that the farmer, who is the main user of the technologies generated by the research, has not been placed as a key element in the development of technologies.

Regarding funding, in recent years the Government has made some efforts to improve the access of funds to research through some lines such as the National Research Fund (FNI) and the Institutional Development Fund (FDI) both belonging to MCTESTP. However, access to such funds is provided based on competitive proposals. Created by decree $12 / 2005$ of June 10 , FNI is a public body endowed with legal personality and administrative autonomy, which has among its attributions to promote, encourage research and finance public entities and others, with a vocation or interest in the development of research, science and technological innovation (Decree of the Council of Ministers, 2010). In 2006, 2007 and 2008, FNI provided funds for research in the following amounts: USD 55,500,000, USD 96,400,000 and USD 1,000,000 respectively (Atanásio, n.d.).

The FDI is a competitive fund also managed by MCTESTP to provide financial support for investments in training and innovation in higher education. This fund is designed to improve the quality and relevance of education through curriculum reinforcement, including the expansion of postgraduate programs, the application of the means to improve teaching and learning and the installation of internship programs in partnership with the productive sector (Parbato \& José, 2015). According to Nordling (2015), Mozambique is a country highly dependent on external funding for research. About $80 \%$ of the funding for research in Mozambique depends on external sources, making it the most dependent country on external funds for research on the African continent. In fact, this percentage is very high, compared to Zimbabwe, which depends on only about $3 \%$ of international funds to conduct its research. The main interpretation that we can draw from these figures is that the research does not seem to be a priority for the public and private sectors in Mozambique, considering the small amount of financial support it has received. Thus, while Mozambique relies heavily on external sources to conduct its research, there is a risk that the country will not be able to establish a national research agenda that is effectively compatible with the demands of local farmers.

In terms of human resources, these are in reduced quantity and quality. The number of researchers in IIAM increased from 93 in 2004 to 163 in 2008. Of these, few are from the area of Sociology and Anthropology, which in a way limits the ability to understand the social factors of productive and reproductive practices of producers (Sitoe, 2014). Specifically in IIAM, there was an increase in the proportion of researchers with the graduation level due to the departure of those with masters and doctoral degrees. Even so, it is important to note that human capital has increased if we take into account that scientific training in Mozambique is very low compared to other countries in Southern and Eastern Africa. Low budgets and unattractive wage levels are increasingly recognized as the major institutional constraints to increasing agricultural research productivity (Sitoe, 2014).

Still on the human capital side, it is important to highlight the role of the Mozambican government in improving the quality of researchers in areas considered as priorities for the country's development. Through various cooperation agreements, the country has been able to award several scholarships for the frequency of postgraduate courses (master's and doctoral degrees) in Mozambique and abroad, in the areas defined as priority areas, including agrarian sciences. Given the limited experience of higher education in Mozambique in the provision of postgraduate courses, especially in the agrarian sciences, almost all doctoral fellows attend their courses abroad. Just over a decade ago, the Government of Mozambique through MCTESTP, have launched annual calls for the award of scholarships to researchers and higher education teachers working in the public sector. On the other hand, the same Government, through the Institute of Scholarships of the MCTESTP, started 
in 2014 the offer of scholarships to teachers of higher education. A significant proportion of these grants are won by researchers of the agrarian sciences, which in the future can improve the technical skills of these researchers and give a new dynamic to Mozambican agrarian research.

Low wages and the lack of better working conditions have led to the abandonment of researchers and extension workers from the public sector to the private sector in search of better wages and working conditions. For example, the Department of Policy Analysis (DAP) of the Ministry of Agriculture has reduced the number of researchers in 2007 from 15 to two (Cunguara et al., 2013). The simple comparison of the number of agricultural researchers in Mozambique with that of some countries shows how critical the situation of human resources in agrarian research in the country is. Mozambique and Rwanda have less than one agrarian researcher per 50,000 inhabitants compared to 1:2,500 in countries like South Africa, Reunion and Mauritius Islands, Libya, Egypt, Cape Verde, Tunisia and Seychelles. In developed countries, the proportion is in the range of 1:400 (Coughlin, 2006). With the creation of the Agricultural Research Technical Council (CTIA) in 1999, IIAM began working on a project aimed at institutionalizing the approach to production systems in agrarian research in Mozambique. However, this initiative has little influence on the programs because, while researchers have begun to test the peasant's agricultural fields, as opposed to trials at experimental stations, the dominant perspective remains the conventional, product-oriented perspective. Nevertheless, according to Sitoe (2014) the current scientific policy has not contributed to generate a process of coproduction of knowledge between scientists and farmers, based on the combination of academic and empirical rationalities. Still, according to the author, the strengthening of the Centre for Socioeconomic Studies can help ensure that the research products and services have a greater impact on communities.

According to Flaherty, Mazuze, and Mahanzule (2010), Mozambican agrarian research has faced challenges that most other Sub-Saharan African countries did not face. In Mozambique, the infrastructure for agricultural research was devastated by the civil war which also decimated the cattle herd. In 2008, for every 100 USD of agrarian GDP, only 41 cents were invested in research and development in Mozambique (Flaherty et al., 2010). This represents a $34 \%$ reduction compared to 2004, when the research intensity was 55 USD cents per 100 USD of agricultural GDP. In the IIAM and in the public sector in general, budgets are systematically cut, which affects the accomplishment of planned activities, leading to dissent with the agricultural calendar (Sitoe, 2014). Although Flaherty et al. (2010) argue that agrarian research in Mozambique faces challenges that other countries did not face, several authors show that in general the challenges faced by most African countries are the weak financial and infrastructure investment for the research, the low number and quality of researchers (Seck et al., 2013; Beintema et al., 2012; Anandajayasekeram et al., 2008; Pardey et al., 1997). It is therefore noticeable that in general African countries face the same problems in agrarian research.

In addition to issues related to budget issues for agrarian research, climate change is a challenge to be addressed. This constitutes a threat to the agricultural sector (Ministry of Agriculture, 2010). According to the UN Food and Agriculture Organization-FAO (2009), climate change negatively affects the basic elements of food production such as soil, water and biodiversity. In this way, small farmers have modified their farming practices to better adapt to climate change. Mozambican agriculture may also be affected by climate change but there are few studies that analyze the adaptive strategies of farmers in the face of this new phenomenon. Of the few existing studies, we highlight Viagem (2013) who simulated the impact of climate change on agriculture in Sussundenga, and Chichongue, Karuku, Mwala, Onyango, and Magalhaes (2015), who evaluated the perception and adaptation measures adopted by farmers in the face of climate change in Sussundenga and Lichinga, Mozambique.

In addition to the climate change phenomenon, the Ministry of Agriculture and Food Security through its Strategic Plan for the Development of the Agrarian Sector questions the sustainability of agroecosystems in Mozambique. This Ministry argues that some factors such as deforestation and soil degradation have been associated with low productivity and agricultural production (Ministry of Agriculture, 2010).

In the last 20 years, several initiatives have been taken to popularize conservation agriculture, mainly in the provinces of Sofala and Manica (Nkala, 2012). However, Grabowski and Mouzinho (2013) show that its adoption is extremely low, standing around $2 \%$ in Agroecological Region 4, which comprises part of the provinces of Sofala and Manica, central region of Mozambique. Silici, Bias, and Cavane (2015) argue that while recognizing the relevance and benefits of sustainable agriculture in Mozambique, there are still few actions that demonstrate the commitment of agricultural research and education institutions. The authors point out that for many reasons, most agrarian research still follows the foundations of conventional agriculture and that in FAEF, the faculty with most experience in offering the agricultural science, sustainable agriculture is approached in different courses, which might make it difficult to understand its relevance. In this way, the challenges related to 
sustainable agriculture in Mozambique are connected with the need for greater commitment from research institutions to the issue of sustainability in agriculture, in all aspects.

Considering the peculiarities of countries and their agrarian research processes is somewhat necessary, however, the fact that they are different does not exclude the possibility of presenting relevant similarities to a broader understanding of research in African countries. An example is several studies that show that climate change and the practice of unsustainable agriculture are issues that threaten the entire African continent (Gowing \& Palmer, 2007; Adenle et al., 2011; Collier et al., 2008; Schlenker \& Lobell, 2010).

Another situation that deserves to be highlighted as a challenge for research and rural extension in Mozambique is the improvement of the partnership between these two institutions, since both aim to contribute to the improvement of agrarian productivity. Moreover, the 2007-2016 Extension Master Plan directs that rural extension should be supported by the Agrarian Knowledge and Information System Approach (AKIS), which calls for strengthening collaboration among farmers, research, extension and higher education institutions in the generation and dissemination of appropriate technologies. It is important to note that in many countries where agriculture continues to be a very important activity in the economy, cooperation between the various actors in agrarian research is also pointed out as relevant. For example, Ifeanyieze, Nwarieji, and Aneke (2017), in their study in southeastern Nigeria, emphasized the relevance of cooperation among research, rural extension and education institutions for the success of technology transfer.

The perspective of collaboration and cooperation between the different actors shows a concern to generate technologies that have the genesis of the subjects themselves, which fits with the perspective of a socially constructed technology (Pinch \& Bijker, 2008). However, this may simply be a mere desire because there is no evidence of such a strong partnership among extension, research and farmers in Mozambique.

\section{Final Considerations}

The early years of the consolidation/expansion of agrarian research in Mozambique were constrained by political and military instability, which in a way affected its effectiveness. Against this background, agrarian research has tried to import the technologies generated from other countries. The main institutions that carry out agricultural research in Mozambique belong to the public sector (IIAM and UEM) and other public or private higher education institutions. However, they do so mainly with external resources, which significantly restricts their autonomy to generate technologies that fully respond to the technological demands of Mozambican agriculture, taking into account their heterogeneity. That way, and in view of the role agriculture plays in Mozambique, there is a need for the Mozambican public and private sectors to improve funding for agrarian research, or it may continue to be guided by the interests of the countries that offer the most funding.

The hiring of more researchers from different fields of knowledge, including those of the Social Sciences, as well as the creation of conditions to retain them, are relevant for strengthening the human component not only of the IIAM, but also of other institutions, taking into account that there are now brain drain, which exacerbates the already scarce human resources. In order for agricultural research to be more compatible with farmers, it is necessary to introduce innovative research approaches involving interdisciplinary teams and to improve linkages with farming families. In fact, strengthening dialogue with farmers is crucial as the focus on increasing production is now focused on knowledge sharing, not just on the use of inputs as in the past.

Currently, agriculture is faced with the new paradigms of climate change and the sustainability of agriculture, which impose the need of agricultural research, using biotechnology, to take advantage of the windows of opportunity offered by these paradigms in order to generate technologies specific to the different realities of farmers. The priority of agrarian research in Mozambique is focused on the cultivation of cassava, maize, peanuts, chickens, goats and sustainable management of forest resources including technologies for the use of wood and forest improvement. Therefore, there is an alignment of research priorities with the characteristics of Mozambican agriculture although some evidence demonstrates the need to improve the incorporation of the needs of farmers in the Mozambican research agenda. However, we note in the list of priorities of agrarian research the exclusion of farmers as relevant elements to be researched considering that these are the most active subjects in agrarian activity. This situation cannot be ignored by Mozambican agrarian research.

Faced with the persistent low adoption of agricultural technologies and the phenomenon of climate change, the research must carry out further studies to analyse the reasons for the low adoption of agricultural technologies and to enumerate the adaptive strategies that farmers follow in the face of climate change. Improving working conditions is essential to improve the partnership between agricultural research and extension. Improving the partnership of these institutions can, in turn, improve the adequacy between the demands of farmers and the technologies to be generated by agrarian research. 


\section{References}

Adenle, A., \& Agboola, J. (2011). Relevant Issues for Sustainable Agriculture in Sub-Saharan Africa. Relevant Perspectives in Global Environmental Change. InTech. https://doi.org/10.5772/39063

Anandajayasekeram, P., Ranjitha, P., Sindu, W., \& Dirk, H. (2008). Concepts and practices in agricultural extension in developing countries. A source book, ILRI.

Atanásio, A. (n.d.). Financiamento da Investigação Científica em Moçambique-o papel da cooperação científica internacional. Retrieved from http://www2.iict.pt/archive/doc/Alsacia_Atanasio.pps

Beintema, N., Stads, G. J., Fuglie, K., \& Heisey, P. (2012). ASTI Global Assessment of Agricultural R\&D Spending: Developing Countries Accelerate Investment. International Food Policy Research Institute.

Benfica, R. (2006). Interlinked Transactions in Cash Cropping Economies: Rationale for Persistence, and the Determinants of Farmer Participation and Performance in the Zambezi Valley of Mozambique. Research Report No. 63E. Maputo, Moçambique.

Bias, C., \& Donovan, C. (2003). Gaps and Opportunities for Agricultural Sector Development in Mozambique. Research Report No. 54. Maputo, Mozambique: MADER, Directorate of Economics, Department of Policy Analysis.

Cavane, E., Cunguara, B., \& Jorge, A. (2013). Adopção de tecnologias agrárias em Moçambique: revisão, interpretação e sintese de estudos feitos. Paper presented at Conference of the Observatory of Rural Environment, Maputo, September 4, 2013. Retrieved September 5, 2016, from http://omrmz.org/omrweb/ wp-content/uploads/cnf-Adopcao-de-Tecnologias-Agrarias-em-Mocambique.pdf

Chichongue, O., Karuku, G., Mwala, A., Onyango, C., \& Magalhaes, A. (2015). Farmers risk perceptions and adaptation to climate change in Lichinga and Sussundenga, Mozambique. African Journal of Agricultural Research, 10(17), 1938-1942. https://doi.org/10.5897/AJAR2013.7360

Collier, P., Conway, G., \& Venables, T. (2008). Climate change and Africa. Oxford Review of Economic Policy, 24(2), 337-353. https://doi.org/10.1093/oxrep/grn019

Coughlin, P. (2006). Agricultural intensification in Mozambique: Infrastructure, policy, and institutional framework-when do problems signal opportunities. Maputo, EconPolicy Research Group.

Cunguara, B., \& Moder, K. (2011). Is agricultural extension helping the poor? Evidence from rural Mozambique. Journal of African Economies, 20(4), 562-595. https://doi.org/10.1093/jae/ejr015

Cunguara, B., Garrett, J., Donovan, C., \& Cássimo, C. (2013). Análise situacional, constrangimentos e oportunidades para o crescimento agrário em Moçambique (No. 153415). Michigan State University, Department of Agricultural, Food, and Resource Economics.

Falcão, M., \& Egas, A. (2008). Situation Analysis of Agricultural Research and Training in the SADC Region. Mozambique.

FAO. (2009). Profile for Climate Change. Rome, Italy.

Flaherty, K., Mazuze, F., \& Mahanzule, R. (2010). Moçambique-Últimos desenvolvimentos na investigação agrária. Maputo: IIAM.

Gemo, H., Eicher, C., \& Teclemariam, S. (2005). Mozambique's experience in building a national agricultural extension system, 1987-2003. National Directorate of Rural Extension. Maputo: DNER, MADER (Ministry of Agriculture and Rural Development).

Gowing, J., \& Palmer, M. (2008). Sustainable agricultural development in sub-Saharan Africa: The case for a paradigm shift in land husbandry. Soil Use Manage, 24, 92-99. https://doi.org/10.1111/j.1475-2743.2007. 00137.x

Grabowski, P., \& Mouzinho, B. (2013). Relatório de Inventário de Agricultura de Conservação em Moçambique. Relatório de Pesquisa No. 6. Maputo, Moçambique.

Ifeanyieze, F., Nwarieji, F., \& Aneke, C. (2017). Linkages of research agencies in technology transfer for sustainable agricultural development in southeast Nigeria. African Journal of Agricultural Research, 12(24), 2063-2069. https://doi.org/10.5897/AJAR2016.11816

INE. (2009). Plano Director do CAP 2009-2010. Maputo, Moçambique.

INE. (2011). Censo Agro-Pecuário 2009-2010: Resultados Definitivos. Maputo, Moçambique. 
IIAM. (2010). Plano Estratégico do IIAM (2011-2015). Maputo, Moçambique.

Jasse, A. (2013). Promoção do Desenvolvimento das Fieiras de Cereais e Oleaginosas Distrito de Nhamatanda-Sofala. Moçambique.

Kit. (2000). PROAGRI: Institutional Reform of the Agricultural Research System. Unpublished report. Amsterdam, Netherlands: Royal Tropical Institute.

Langa, P. (2012). A Mercantilização do Ensino Superior e a relação com o saber: a Qualidade em Questão. Revista Científica da UEM: Série Ciências da Educação, 1(1), 21-41.

Luby, C., Kloppenburg, J., Michaels, T., \& Goldman, I. (2015). Enhancing freedom to operate for plant breeders and farmers through open source plant breeding. Crop Science, 55(6), 2481-2488. https://doi.org/10.2135/ cropsci2014.10.0708

Ministry of Agriculture. (2010). Plano Estratégico Para o Desenvolvimento do Sector Agrário 2010-2019. Maputo, Moçambique.

Ministério Para a Coordenação da Acção Ambiental. (2005). Avaliação da Vulnerabilidade as Mudanças Climáticas e Estratégias de Adaptação. Maputo, Moçambique.

Mosca, J. (2011). Políticas agrárias de (em) Moçambique, 1975-2009. Livraria Escola Editora, Lisboa.

Nkala, P. (2011). Assessing the impacts of conservation agriculture on farmer livelihoods in three selected communities in central Mozambique (Doctoral dissertation, University of Natural Resources and Life Sciences, Austria). Retrieved from http:/www.boku.ac.at/fileadmin/data/H04000/H16900/Resources/ Scientific_Pub/Peter_Nkala_2012_.pdf

Nordling, L. (2015). Africa aims for research autonomy. Nature, 520(7546), 142-143. https://doi.org/10.1038/ $520142 \mathrm{a}$

Parbato, D., \& José, S. (2015). Manual Operacional do Fundo de Desenvolvimento Institucional-FDI. Maputo, Moçambique.

Pardey, P. G., Roseboom, J., \& Beintema, N. M. (1997). Investments in African agricultural research. World Development, 25(3), 409-423. https://doi.org/10.1016/S0305-750X(96)00113-1

Pinch, T., \& Bijker, W. (2008). La construcción social de hechos y artefactos: O acerca de como la sociologia de la ciencia y la sociologia de la tecnologia pueden beneficiarse mutuamente. In H. Thomas \& A. Buch (Eds.), Actos, actores y artefactos: Sociologia de la tecnologia. Bernal: Quilmes Editorial.

Romeiro, A. (1998). Meio ambiente e dinâmica de inovações na agricultura. Annablume Editora.

Schlenker, W., \& Lobell, D. (2010). Robust negative impacts of climate change on African agriculture. Environmental Research Letters, 5(1), 014010. https://doi.org/10.1088/1748-9326/5/1/014010

Seck, P. A., Agboh-Noameshie, A., Diagne, A., \& Bamba, I. (2013). Repackaging agricultural research for greater impact on agricultural growth in Africa. Journal of Food Security, 1(2), 30-41. https://doi.org/ $10.12691 /$ jfs-1-2-4

Silici, L., Bias, C., \& Cavane, E. (2015). Sustainable agriculture for small-scale farmers in Mozambique: A scoping report. International Institute for Environment and Development, London.

Sitoe, T. (2005). Agricultura Familiar em Moçambique-Estratégias de desenvolvimento sustentável. Maputo, Mozambique.

Sitoe, T. (2014). Os desafios da investigação agrária em Moçambique. Desenvolvimento em Questão, 12(25), 81-104. https://doi.org/10.21527/2237-6453.2014.25.81-104

Snapp, S., Blackie, M., \& Donovan, C. (2003). Realigning research and extension to focus on farmers' constraints and opportunities. Food Policy, 28(4), 349-363. https://doi.org/10.1016/j.foodpol.2003.08.002

Tomo, A. (2009). Economic impact of Newcastle disease control in village chickens: A case study in Mozambique. Michigan State University.

Uaiene, R. (2011). Determinantes para a Adopção de Tecnologias Agrícolas em Moçambique. Retrieved from http://fsg.afre.msu.edu/mozambique/caadp/Uaiene_Adopcao_Tecnologias_Pt.pdf

Viagem, S. (2013). Simulação do impacto das mudanças climáticas sobre a agricultura irrigada da região de Sussundenga-Moçambique (Master's thesis, Federal University of Rio Grande de Sul, Brazil). Retrieved from http://www.lume.ufrgs.br/handle/10183/95650 
Walker, T., Pitoro, R., Tomo, A., Sitoe, I., Salencia, C., Mahanzule, R., \& Mazuze, F. (2006). Priority Setting for Public-Sector Agricultural Research in Mozambique with the National Agricultural Survey Data (TIA), Research Report Series. Retrieved from http://ageconsearch.umn.edu/bitstream/56113/2/rr_3E.pdf

\section{Notes}

Note 1 . As mentioned above, the average family agricultural area has been reduced from 1.5 ha to 1.4 ha between 2008 and 2012.

Note 2. IIAM is the largest public research institution in the agrarian area and is supervised by the Ministry of Agriculture and Food Security, former Ministry of Agriculture.

\section{Copyrights}

Copyright for this article is retained by the author(s), with first publication rights granted to the journal.

This is an open-access article distributed under the terms and conditions of the Creative Commons Attribution license (http://creativecommons.org/licenses/by/4.0/). 